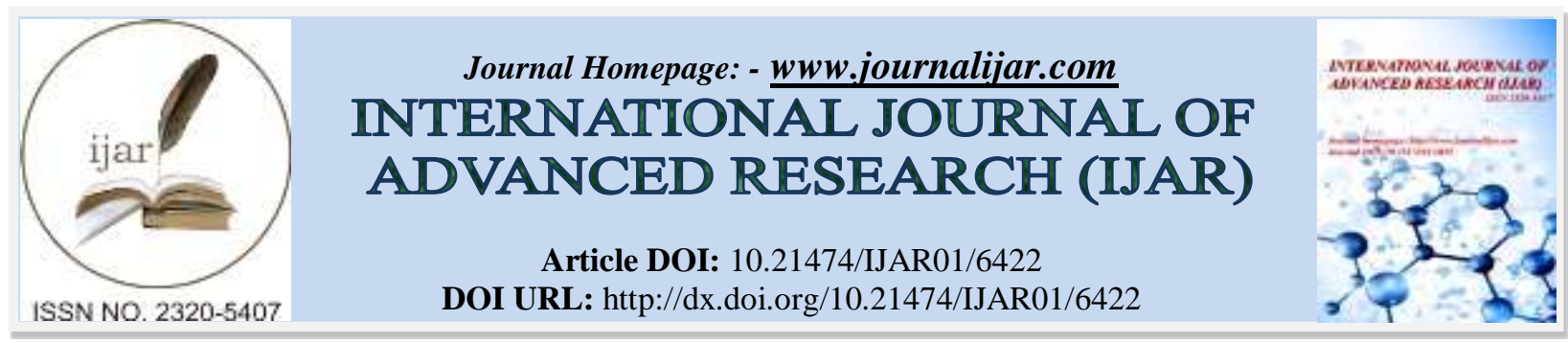

RESEARCH ARTICLE

\title{
GOODS AND SERVICE TAX “ONE NATION ONE TAX” IN INDIA.
}

\author{
Shuchi Sharma ${ }^{1}$ and Dr. Rupendra Prakash Yadav ${ }^{2}$.
}

1. PhD Scholar, School of Law, Sharda University, Greater Noida, Uttar Pradesh, India.

2. Associate Professor, Sharda University, Greater Noida, Uttar Pradesh, India.

\section{Manuscript Info}

Manuscript History

Received: 02 December 2017

Final Accepted: 04 January 2018

Published: February 2018

Key words:-

Goods and Service Tax (GST), GST

Models CGST and SGST.

\begin{abstract}
Goods and Service Tax is a significant and logical step towards a comprehensive Indirect tax reform in India. This paper analyses the concept of Goods Service Tax and further discusses their impact on the various sectors in India. Brief description is given on Goods Service Tax background and Goods and Service Tax models helps to reduce tax burden. It aims at creating a single and unified market benefiting both corporate and economy because this is the only Indirect tax that directly affects all sectors of economy, subsuming of many indirect taxes having a dual concept model operating at centre (CGST) and state (SGST) to maintain commonality.
\end{abstract}

Copy Right, IJAR, 2018,. All rights reserved.

\section{Introduction:-}

Today, the processes of 'Globalization' and 'Digitization' have transformed the trade, commerce and lifestyles across the globe. In this era of rapid technological evolution and ever changing consumption patterns change is the only constant thing to address the needs of changing societies and keep pace with the ways in which people conduct their business it is imperative that archaic laws are abolished and new ones are engineered to enhance relevance and adapt to the contemporary modes of doing business.

At the verge of this success path when our economy can take off, there is burning need for widening the tax base, adopt measures for increasing tax collections, simplification and rationalization of tax laws. E- Governance of such tax laws becomes the sine-qua-none for its grand success. The introduction of GST shall play an important role in the economic development of the country to give it the desired inputs. This mechanism by self enforcing mechanism, in the era of globalization and technological changes, we must realize the need to be far more proactive to respond to the challenges. Our strategy must be multi prolonged a part from laying emphasis on educational standards and technical standards.

We wish that our leaders and bureaucrats must shoulder their responsibilities with excellence, independence and integrity. We must therefore, whole heartedly welcome the biggest ever fiscal reform in our country to make it super power in the world economy. GST will have fiscal unification and replace a thicket of indirect tax levies India impose as on today. Goods and Services Tax (GST) is most ambitious and biggest tax reform plan, which aims to stitch together a common market by dismantling fiscal barriers between states. It is a single national uniform tax levied across India on all goods and services. In GST, all the indirect taxes will be subsumed under a single regime. The GST taxation laws will put an end to multiple taxes which are levied on different products, starting from the source of manufacturing to reaching then end consumer. GST works on the fundamental Principle of "One Country One Tax". 


\section{Statement of Problem:-}

In the present tax system the Goods and Service Tax (GST) subsumes the various taxes and avoids the problem of multiple taxation and the other indirect taxes having cascading effect and reducing the tax burden. Through Goods and Service Tax creating a single and unified market to make economy stronger and remove the barriers between states and integrating India uniform tax rates.

\section{Research Methodology:-}

The study focuses on exploratory research. The researcher has used secondary data collected from various books, National and International Journals, government reports, publications from various websites which focuses on various aspects of tax structure and goods and services tax.

\section{Objectives of Study:-}

- To analyse the concept of Goods and Service Tax (GST) in India

- To examine the Goods and Service Tax mechanism reduces the tax burden and removes the multiple taxation and other cascading effects.

\section{Evolution of Goods and Service Tax (GST) in the Indian Context}

Tax policies play a vital role on the economy. The main source of revenue for government of India is from tax. Direct and indirect taxes are the two main source of tax revenue. When the impact and incidence falls on same person it is called direct tax. When the impact and incidence falls on different person that is when burden can be shifted to other person it is called indirect tax. The indirect tax system is currently mired in multi-layered taxes levied by the Centre and state governments at different stages of the supply chain such as excise duty, Octroi, central sales tax (CST) and value-added tax (VAT), among others. First Indirect Tax Reform occurred in India when the Modified Value Added Tax (MODVAT) was introduced for selected commodities in 1986 to replace the Central Excise Duty. The other reforms are the introduction of service tax in 1994, decision to introduce VAT in 1999, introduction of Constitution Amendment Bill on GST in 2011.

\section{Kelkar Task Force (2003) proposed GST:-}

The Goods and Service Tax firstly introduced by report of the Kelkar Task Force (2003) on indirect taxes. We have enlisted the major milestones on the proposal for introduction of GST in India. In 2006, a proposal to introduce Goods and Service Tax at national level by April 1, 2010 was first mooted in Budget Speech for the financial year 2006-2007. A Joint Working Group consisting of officers from Central as well as State Government was constituted in September, 2009.the Empowered Committee of State Finance Minister was assigned to prepare the design and road map for the implementation of GST

Constitutional $115^{\text {th }}$ Amendment proposed: In regard to amend the Constitution to enable introduction of GST, the Constitution (115th Amendment) Bill, 2011 to give concurrent taxing power to the Union and States was introduced in Lok Sabha. The Bill suggested the creation of Goods and Service Tax Council \& Goods and Services Tax Dispute Settlement Authority. The Bill was lapsed in 2014 and was replaced with the Constitution (122nd Amendment) Bill, 2014. The Empowered Committee has decided to constitute three committees of officers to discuss and report on various aspects of GST as follows:

1. Committee on Place of Supply Rules and Revenue Neutral Rates.

2. Committee on dual control, threshold and exemptions

3. Committee on IGST and GST on imports.

The final draft of Constitutional Amendment Bill incorporating the above stated certain changes were sent to the Empowered Committee (EC) for consideration. The Empowered Committee once again made certain recommendations on the Bill after its meeting in Shillong. Certain recommendations of which were incorporated in the draft Constitution (115th Amendment) Bill and the revised draft was again sent to Empowered Committee for its consideration The draft Constitution Amendment Bill in March, 2014 was sent to the Empowered Committee after approval of the new Government.

\section{4-2015 Constitutional Amendment passed by Lower House:-}

The Constitution 122 ${ }^{\text {nd }}$ (One Hundred and Twenty-Second Amendment) Bill, 2014 seeking to amend the Constitution to introduce the Goods and Services Tax (GST) and subsume state Value Added Tax, Octroi and entry 
tax, luxury tax, etc. was introduced in the Lok Sabha on December 19, 2014 by the Hon'ble Minister of Finance, Mr. Arun Jaitley.

Constitution Amendment (122nd) Bill was passed by Lok Sabha on May 06, 2015. In Rajya Sabha, Bill was referred to a 21-member Select Committee of Rajya Sabha. Select Committee submitted its report to Rajya Sabha on July 22, 2015.

2016: Watershed Year - GST became a reality:-

August, 2016: After almost a gap of one year, on August 03, 2016, the Constitution (122ndAmendment) Bill, 2014 was passed by Rajya Sabha with certain amendments. The changes made by Rajya Sabha were unanimously passed by Lok Sabha, on August 08, 2016. After this giant leap forward, 21 states (of more than 50\% of Indian States) ratified the Constitutional Amendment and finally the Bill received Presidential Assent on September 8, 2016.Final assent of Hon'ble President of India was given on 8th September, 2016 Parliament passed the following four bills:

1. Central Goods and Services Tax (CGST) Bill

2. Integrated Goods and Services Tax (IGST) Bill

3. Union Territory Goods and Services (Compensation to States ) Bill

April, 2017: President's assent was given to four key legislations on Goods and Services tax.

Concept of Goods and Service Tax:-

GST is distinct from turnover tax; in the sense that it is imposed at each stage of commercial transactions from initial producer to the final consumer identified with VAT mechanism by providing credit for the tax on inputs. There is difference between supply and sales.VAT is chargeable at each stage of supply of goods and services may it be from manufacturer, whole seller or a retailer, principal or agent, down the chain of distribution until it reaches to the final consumer. This is the reason that this tax system is also called transaction tax or consumer or consumption based tax. GST is consumption based tax i.e. Tax will be payable in the state in which goods and services finally consumed.

GST, as a well-designed value added tax on all goods and services, is the most elegant method to eliminate distortions and to tax consumption. Taxes which have been subsumed under the GST are follows as:

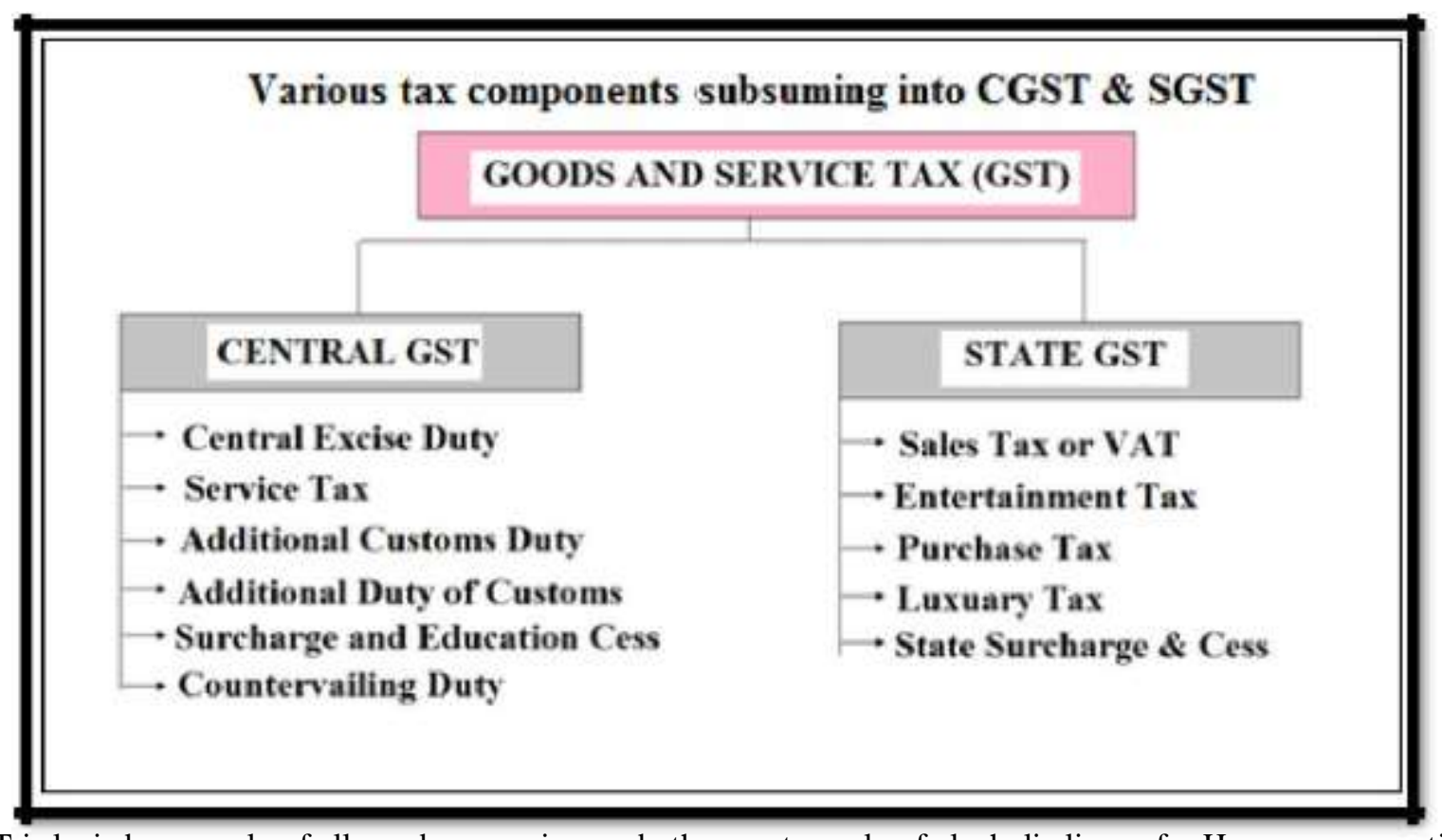

GST is levied on supply of all goods or services or both except supply of alcoholic liquor for Human consumption. Five petroleum products viz. petroleum crude, motor spirit (petrol), high speed diesel, natural gas and aviation turbine fuel have temporarily been kept out and GST Council shall decide the date from which they shall be included in GST. Electricity has also been kept out of GST. 


\section{Models of Goods and Service Tax:-}

The structure provided under GST is dual in nature and under this; the Centre and the States simultaneously levy tax on a common base. Section 2(21) says that "CGST" means the tax levied under the Central Goods and Services Tax Act, 2016. The GST levied by the Centre on intra-State supply of goods and / or services is called the Central Goods and Service Tax (CGST). Section 2(56) says that "inter- State Supply of goods" means the supply of goods in the course of intra-State trade or commerce in terms of section4 (1) of IGST Act, 2016. Section 2(93) says that "SGST" means the tax levied under the State Goods and Services Tax Act, 2016. The GST levied by the States/ Union territory is called the State Goods Service Tax (SGST)/ UTGST. Similarly, section 2(51) says that "IGST" means the tax levied under the Integrated Goods and Services Tax Act, 2016. Integrated Goods Service Tax (IGST) is levied and administered by Centre on every inter-state supply of goods and services.

\section{Goods and Services Tax Rates:-}

The four GST slabs have been set at $0 \%, 5 \%, 12 \%, 18 \%$ and $28 \%$ for different goods and services. The integration of tax laws in Goods and Service Tax is expected to reduce the tax burden on the tax payer compared to present system where the tax burden is high.

Presently the tax is at two points of consideration when the product moves out of factory and other at the retail outlet. Further that the GST is to be levied at final destination of Consumption and not at various points.

\section{Impact of Goods and Service Tax on Various Sectors:- Automobile Sector:}

This industry may be positively affected with expectation that tax rates would be lowered at least on vehicles for lower segment. The commercial vehicles manufactures segment may be adversely affected due to the reason of ease of logistics hurdles. With fleet productivity increase, the operators may not feel the need to add vehicles in the near future.

\section{Fast Moving Consumer Goods Sector (FMCG):}

FMCG companies can eliminate setting up of multiple sales depots and thus can save on account of logistics and distribution costs. Such companies at present pay about 25\% taxes comprising Excise duty, VAT and Entry tax etc. however it is expected that the new levy under GST may be kept $18 \%$.

\section{Hospitality Industry:}

The food and beverages bills of such companies are subject to levy of multiple taxes in the range of 30-35\%. A uniform rate of say $18 \%$ will benefit consumers of such industry. Multiplicity of the provisions in relation to luxury tax across the sates may migrate the problems of such industry. On global front, most of the countries tax food at a lower rate keeping in view the considerations of fairness and equity. Even in countries such as Canada and Australia where food constitute a relatively small portion of the consumer basket, food is taxed at zero rates. Even in international jurisdictions, no distinction is drawn on the degree of processing of food. Hence, the benefit of lower or zero tax rates should also be extended to all food items in India regardless to degree of processing.

\section{Information Technology Industry:}

Such companies are normally set up in special economic zones (SEZs). Such companies get their inputs without having paid any taxes. However, in the GST law the benefit of exemption of inputs to SEZs would be through refund mechanism. This will entail additional working capital and will adversely affect this sector.

\section{Cement Industry:}

At present such companies pay taxes in the form of Excise duty and VAT, approximately 25\%. If they are kept subject to levy of GST at a standard rate $18 \%$ their tax burden would be reduced. Further such companies may save on account of transportation / warehousing costs which also comprises up to $20 \%$ of total revenue of these companies.

\section{Textile Industry:}

It is imperative that the entire chain of textile industry right from procurement of agriculture produce in the form of cotton to final apparel should be brought under GST regime so that there may not be any cascading of taxes and the chain of inputs will maintained. It is expected that the sector would be kept in the lowest tax slab 
under the proposed regime. The tax rates can be fixed $8 \%$ for cotton textiles and $12 \%$ on blended and manmade fiber based products.

\section{Conclusion:-}

A well designed GST is an attractive method to get rid of deformation of the existing process of multiple taxation also government has promised that GST will reduce the compliance burden at present there will be no distinction between imported and Indian goods and they would be taxed at the same rate. Many Indirect Taxes will Sales tax, VAT etc will be finished due to there will be one tax system.

\section{References:-}

1. A.N, Kumar, Shah Deo, and Prerna Kittu Singh. "GST: India's New Journey towards Indirect Taxation." International Journal of Science and Research 6, no. 7 (July 2017).

2. Garg, Girish. "Basic Concept \& Features of GST in India." International Journal of Scientific Research \& Management 2, no. 2 (2014): 542-549.

3. Khurana, Akanksha, and Aastha Sharma. "Goods and Service Tax in India: A Positive Reform for Indirect Tax System." International Journal of Advanced Research 4, no. 3 (2016): 500-505.

4. Kumar, Dr.Mohan, and CA Yogesh Kumar. "GST \& its Probable Impact on the FMCG Industry in India." International Journal of Research in Finance and Marketing 7, no. 4 (2017): 66-76.

5. Shah, Suraj M., and Dr. Nirav R Joshi. "Tax Reform for Developing Viable and Sustainable Tax System with Special Reference to GST." International Journal of Management (IAEME) 8, no. 1 (Jan-Feb 2017): 119-126.

6. Soni, Dr. Shri Prakash G., Mr. Sumit Omprakash Bahiti, Mr.Govind Pravin Chandak, and Mr. Akshta Girish Suri. "GST- A Paradigm Shift in Indirect Taxes." International Journal of Research in Economics and Social Sciences 2, no. 2 (2017): 160-167.

7. T.I, Sherline. "India Tax Structure \& Relevance of GST." International Journal of Commerce, Business and Management 5, no. 06 (2016).

8. V.M, Jasmine. "GST \& Evolution of Tax System in India." International Journal of Management \& Social Science 07, no. 01 (2017): 65-72. 